\title{
The Incognito of a Thief \\ Johannes Climacus and the Poetics of Self-Incrimination
}

\author{
Martijn Boven
}

[This is a draft version of: Boven, Martijn. (2019) 'The Incognito of a Thief: Johannes Climacus and the Poetics of Self-Incrimination,' in Adam Buben, Eleanor Helms, and Patrick Stokes (eds.), The Kierkegaardian Mind, London: Routledge, 409-420.]

\begin{abstract}
In this essay, I advance a reading of Pbilosopbical Crumbs or a Crumb of Pbilosopby, published by Søren Kierkegaard under the pseudonym Johannes Climacus. I argue that this book is animated by a poetics of self-incrimination. Climacus keeps accusing himself of having stolen his words from someone else. In this way, he deliberately adopts the identity of a thief as an incognito. To understand this poetics of self-incrimination, I analyze the hypothetical thought-project that Climacus develops in an attempt to show what it means to go further than Socrates. In my reading, I distinguish between a Socratic and a non-Socratic conception of education, both of which rely on an incognito. Socrates takes on the maieutic incognito of an ignorant bystander in order to force his interlocutors to turn inward so that the truth that is already within them can be born. In contrast, the non-Socratic education that Climacus advances as a hypothesis relies on what I call 'the incognito as a true form'. It is an incognito insofar as it confronts the pupils with a paradox on which the understanding runs aground. It is a true form insofar as its immediate appearance is not a disguise, but a true form. This indirect mode of communication is necessary, without it pupils will not be able to encounter a truth that is not inherent within them. Climacus' poetics of self-incrimination, I argue, tries to repeat this indirect mode of communication by adopting the incognito of a thief as a true form.
\end{abstract}

\section{INTRODUCTION}

Søren Kierkegaard's Philosophiske Smuler eller En Smule Philosophi (Philosophical Crumbs or a Crumb of Philosophy) was published in 1844 under the pseudonym Johannes Climacus. ${ }^{1}$ As the connective 'or' (eller) already suggests, the book has no singular form, but can be interpreted either as multiple philosophical crumbs or as a single crumb of philosophy. ${ }^{2}$ This announces a tension between the outer forms in which the book manifest itself (the philosophical crumbs) and the inner existential insight that is expressed in this way (the crumb of philosophy). Apparently the plural manifestation is the only mode in which the singular existential insight can emerge. It cannot be stated directly, but can only unroll itself in contrastive forms that preserve its innerness through tensions and contradictions that still need to be resolved by the reader. In this essay, I show that these indirect and contrastive forms are animated by a poetics of self-incrimination. By adopting the identity of a thief as an incognito, I argue, the pseudonymous author Johannes Climacus tries to recharge the absolute paradox that he invents/discovers at the heart of Christianity.

\section{Selfincrimination}

Climacus' poetics of self-incrimination is already announced in the motto of the book: 'Better well hanged than ill wed' (PF, 3/SKS 4, 214). This echo of the reckless and provocative words of Feste, the jester from Shakespeare's Twelfth Night, sets the tone for the entire book (2003: 70). ${ }^{3}$ It indicates that Climacus would rather be seen as a criminal (and face the consequences) than join speculative scholarship in its attempts to mediate the offensive nature of Christianity and make it 
respectable as part of a progressive moment in the development of the Hegelian system. In line with the motto, Climacus deliberately provides the reader with a series of self-incriminating statements.

At crucial moments in Philosophical Crumbs, Climacus interrupts his own argument by introducing an imaginary opponent who accuses him of stealing his words from someone else. These accusations do not come from outside, but are an integral part of Climacus' own dialogic discourse. They usually begin with a phrase like 'perhaps someone will say' or 'if someone were to say, followed by an accusation of theft or plagiarism. This practice of self-incrimination becomes a signature mark for the whole book. By adopting the incognito of a common thief, Climacus puts his own authority in question and dialogizes his own project. At the same time, he bolsters his project by suggesting that he did not steal his ideas from just anybody, but that they originated with 'the god' (guden). Moreover, he suggest that theft is the condition for getting access to these ideas, regardless of whether we use them for an attack or for a defense of Christianity. Theft evokes 'sin' and 'guilt,' and the kind of education Climacus advances (as a hypothetical project) can only commence by accepting these incriminations.

Quite a few interpreters (Evans 1992; Fenves 1993; Mulhall 1999; Hale 2002; Conway 2004; Pons 2004; Howland 2006; Muench 2006) have highlighted the role of the imaginary opponent and his accusations of theft and plagiarism. I want to push this point a bit by arguing that it is ultimately Climacus himself who is the source of the accusations that are brought against him. By interrupting his own discourse with dialogical accusations, Climacus invites his readers to join in the ambiguous self-incrimination that he is enacting. In this way, I argue, he deliberately adopts the identity of a thief as an incognito. The aim of this is to re-activate the offensive nature of Christianity, demanding a gesture of self-incrimination as a response, in order to force his readers to take a stance.

If we look at the composition of Philosophical Crumbs, it is constructed as a comedy with five acts, preceded by a preface, cut in two by an interlude, and concluded with a moral. This comedy employs several variations on Climacus' incognito of the thief. In chapter 1, Climacus develops a thought-project that, by way of hypothesis, investigates what it means to really 'go further' than Socrates. ${ }^{4}$ In the process, he accidentally invents a shadow version of Christianity. Here Climacus adopts the incognito of the thief by presenting himself as a project maker who advances a false claim to an invention that ultimately belongs to no one else than the god. Chapter 2 is composed as a poetical venture, the authorship of which is not clearly assigned but keeps shifting. Climacus, as the disputed writer of this poetical venture, appears in the incognito of a plagiarizer who ends up stealing his words from the god himself. In chapter 3, Climacus takes on the incognito of a capricious fellow who introduces a seemingly ludicrous and completely unreasonable conception that deliberately aims for the collapse of the understanding. In the appendix to this chapter, the incognito of the thief gets a new twist when Climacus admits that he has only been parroting the paradox. In chapter 4 and 5 , the poetical venture is taken up again but the accusatory mode of speaking of the imaginary opponent is now mixed with a laudatory mode of speaking. In this way, it simultaneously enacts the dismissive logic of an attack and the jubilant logic of a defense, both of which turn out to be equally problematic. In addition to the five chapters, Climacus inserts an interlude that addresses the difficult issue of coming into existence. This interlude plays with the contrast between the ordinary function of the interlude (shorten time by filling it up with a diversion) and the way it is used here (prolonging time by discussing the most complicated concepts of the whole book). 


\section{THE MAIEUTIC INCOGNITO}

The first chapter of Philosopbical Crumbs is announced under the title 'Thought-Project.' Climacus argues that the speculative scholarship of his day, despite its attempt at 'going further' than Socrates, ultimately comes down to re-affirming the Socratic conception of recollection. 'All these ideas are that Greek idea of recollection, although this is not always noticed, because they have been arrived at by going further [gaae videre].' (PF, 10, note */SKS 4, 219) In this way, he identifies speculative scholarship with the Socratic position it supposedly had moved beyond. Climacus presents his thought-project as an experiment in which he will explicate, by way of a hypothesis, what it would mean to really go further than Socrates. It is not easy to summarize this hypothesis, but it goes something like this: if there is a philosophical position that moves beyond Socrates, it must involve a different conception of truth. Socratically speaking, all people have access to the truth through recollection; the condition for reaching this truth is already present within themselves. Going further than Socrates means that this is no longer the case. Instead, the access to the truth is blocked and the condition for reaching it needs to come from somewhere else.

Despite its attempt at going further, Climacus' thought-project overlaps on one important point with the Socratic dialogue: the need for an indirect form of communication. This can be achieved by adopting an incognito (see e.g. Boven 2014, 2018; Muench 2006). In this way, both Climacus and Socrates can ensure that their recipients start to question their own position and turn inwards, rather than simply copying the ideas of an external authority. The term 'maieutic' is derived from Plato's Theaetetus, in which Socrates compares himself to a midwife (maia) (1921, 34-5/150c). Like a midwife, Socrates can only assist others in giving birth, but remains barren of wisdom (agonos sophias) himself (Ibid.). Climacus believes that, humanly speaking, assisting others is the highest goal one can achieve with education. As he states, 'between one human being and another maieuesthai [serving as a midwife] is the highest; giving birth [fode] indeed belongs to the god' (PF, 11/SKS 4, 220; translation modified). ${ }^{5}$ In Climacus' estimation, going further than Socrates means substituting the Socratic conception of recollection (Erindring) with a conception of rebirth (Gjenfodelse). This constitutes a shift from the Socratic position of a midwife (who assists others to give birth) to the position of a divine creator (who literally gives birth to others). Climacus, as a human being who addresses himself to other human beings, cannot really go further than Socrates and has to stick to a maieutic incognito.

Although Socrates and Climacus use the maieutic incognito for different reasons, its underlying structure is more or less the same. Let us first look at the role of the maieutic incognito in the Socratic dialogues. Given the prominent role Plato's Meno plays in Pbilosophical Crumbs, we will take this dialogue as an example. At the start of the dialogue, Socrates adopts the incognito of an ignorant bystander who is willing to accept Meno as his master. Initially Meno is happy to take on this role. He presents himself as an authority on the question "what is virtue?" and invokes other authority figures like Gorgias in the process. Socrates, on the other hand, presents himself as someone who has no authority to speak about virtue and openly questions authority figures that claim to know all about it. ${ }^{6}$ By adopting the incognito of an ignorant bystander who only asks a few innocent questions, Socrates forces Meno to admit that he does not know what virtue is and that the issue is in fact perplexing him. In the course of the argument, Socrates complicates the opposition between mastery and slavery on which Meno's 
initial definition of virtue is based. ${ }^{7}$ This comes to a climax in the famous episode in which Socrates questions one of Meno's slaves about geometry. By putting the slave in a position where he-like his master Meno-thinks that he can 'easily make many fine speeches to large audiences,' Socrates ironically identifies the master with his slave (Plato 1997: 883-4/84c). ${ }^{8}$ Moreover, he shows that, upon questioning, the slave-unlike his master Meno-is willing to admit that he is at a loss and that his previous claim of authority was utterly mistaken. In other words, in a few simple steps the slave has already surpassed his master in dialectical reasoning. The slave episode is not only an effective mockery of Meno's assumed authority and mastery; it also provides a blueprint for the kind of education that Socrates is propagating.

This kind of education proceeds in two steps. First, by adopting the incognito of the ignorant bystander, Socrates provokes his interlocutor-Meno or his slave-to formulate whatever he thinks he knows about the subject in order to let him run aground on a series of contradictions and difficulties. ${ }^{9}$ The aim of this is to make an all too confident interlocutor perplexed, 'numbing him as the numbfish does' and to expose the one-sided nature of his assumptions (Plato 1997: 883/84b, translation modified). In this way, interlocutors become aware that they do not really know what they thought they knew. Instead of relying on assumptions and authorities, they are turned inward and start to long for the truth that is already within them. As a second step, Socrates will remind them of this truth, encourage them to discover it, and let them bring it to light. To determine whether they really gave birth to the truth and not to some kind of phantom, he will subsequently subject their offspring to all possible tests.

From Climacus' perspective, leaving the Socratic viewpoint means that human beings can no longer be defined as having the truth already within them. Instead, they now have to be 'defined as being outside the truth' (PF, 13/SKS 4, 222). As seen from this new perspective, education still proceeds in two steps. The first step still consists of making pupils aware by turning them inwards. However, it can no longer be understood as a progressive movement that brings the pupils closer to the truth within themselves. On the contrary, this first step rather generates a regressive movement that only shows pupils that they are 'not coming toward [kommende til' the truth, but are rather 'going away from [gaaende fra]' it (Ibid.). Rather than being reminded of the truth within themselves (the Socratic viewpoint), pupils are turned inward by letting them discover that they are outside of the truth; as such, they are confronted with their own untruth. This state of untruth cannot be communicated directly, but can only be revealed indirectly. Climacus formulates this as follows: 'I can discover my own untruth only by myself, because only when $I$ discover it is it discovered, not before, even though the whole world knew it' (PF, 14/SKS 4, 223).

Despite the difference in outcome, the thought-project achieves its effects in a similar way as the Socratic dialogue. In both cases, the first step of education can only be attained by provoking the pupil to turn inward with the help of an indirect form of communication that relies on adopting an incognito. Here 'the teacher is only an occasion, whoever he may be, even if he is a god' (Ibid.). Climacus tries to achieve this effect by presenting himself as a project maker who advances a false claim to an invention that ultimately belongs to no one else but the god. The aim of his ambiguous discourse is to set the first step of education in motion. This prepares the way for the second step, which constitutes a rebirth through which the pupil first receives the condition for discovering the truth. Climacus cannot make this second step happen; it is the prerogative of the god. 


\section{AN INVENTION WITHOUT AN INVENTOR}

At the end of the first chapter, Climacus explicitly hints at his own incognito of a thief. First he claims ownership of his project: 'Look, this is my project [Projekt]! (PF, 21/SKS 4, 229; translation modified). The next moment, however, an imaginary opponent interrupts his discourse, arguing that this project does not in fact belong to Climacus. 'This is the most ludicrous of all projects [Projekter], or, rather, you are the most ludicrous of all project makers [Projektmagere], for even if someone projects [projekterer] something foolish, at least the truth remains that he was the one who projected [projekteret] it' (PF, 21/SKS 4, 229; translation modified). At issue is not so much the content of the project, but the assumption that Climacus is the one who projects it. The opponent reproaches Climacus for 'behaving like a scoundrel who charges a fee for showing an area that everyone can see,' someone 'who in the afternoon exhibited a ram for a fee, although in the morning anyone could have seen it free of charge, grazing in the open pasture' (Ibid., translation modified). In other words, Climacus is accused of taking credit for something that is not at all his own invention.

In his response to these self-incriminating accusations, Climacus complicates matters further by taking two further possibilities into consideration. First he suggests that the invention of his project might be similar to the invention of gunpowder. 'Admittedly, gunpowder was invented centuries ago; so it would be ludicrous of me to pretend that I had invented it. But would it also be ludicrous for me to assume that someone had invented it?' (PF, 21/SKS 4, 22930). In that case, Climacus would be guilty of stealing intellectual property. However, if we take into account what has been invented (e.g. a certain conception of nonexistence that precedes rebirth), it is more likely that nobody invented it. 'Is it not odd that something like this exists, of which everyone who knows about it also knows that he did not invent it, and that this "Go to the next house" does not stop and cannot be stopped, even if one would go to every human being?' (PF, 22/SKS 4, 230; translation modified).

Climacus keeps changing roles. At first he appeared as the inventor of his own project, then as someone who has stolen it from another human inventor, and finally his project turns out to be invented by nobody at all, at least not by a human being. This last option-the invention without a human inventor-fascinates Climacus greatly, 'for it tests the correctness of the hypothesis and demonstrates it' (Ibid.). Here we see that Climacus sees the incognito of a thief as an essential part of his argument. It even provides proof for his hypothetical thoughtproject. Why is this so? It is not easy to answer this question, as it is part of a complicated play that involves the book as a whole. Nonetheless, a first answer can already be given by reflecting on the second step of education: the rebirth of the pupil.

In Climacus' view, the conception of a rebirth implies a preceding state of nonexistence in which the pupil is defined by untruth and has no way of getting access to the truth. 'It would indeed be preposterous to expect that a human being can discover all by himself that he does not exist [ikke var til. But this is the transition inherent to rebirth: from "not existing [ikke at vare til]" to "existing [at vare til]" (Ibid.; translation modified). It is for this reason that rebirth-which, following the hypothetical logic of the thought-project, is implied by going further than Socrates-can only be understood as an invention without a human inventor. It is not possible to discover one's own nonexistence and invent a way out of it. However, as we saw, pupils still have to become aware of their own untruth. If someone else does it for them, they do not learn anything new and there will be no transition from untruth to truth. According to Climacus, this 
transition is tied to what he calls 'the blink of an eye (Øieblik),' an ordinary Danish word which simply refers to a very short time-span, an instant. It is within the blink of an eye that the pupil is turned inward and confronted with his or her own untruth. Whether this confrontation results in a rebirth is determined by how the pupil decides to react to this confrontation. The offended pupil is pushed away by the confrontation; the pupil who has faith makes the transition from untruth to truth.

To get a better sense of how this confrontation with untruth takes place, Climacus has to get a sense of the incognito of the god. In contrast to Socrates, who relied on a maieutic incognito, the god adopts the incognito as a true form. This incognito is necessary to ensure that the first step of education (turning the pupil inward) takes place. In addition, it also provides the condition for the second step (generating a rebirth), regardless of whether this second step takes place or not. The incognito as a true form is a bit of a counter-intuitive notion. The second part (as a true form) immediately seems to cancel the first (incognito). This can be clarified with the help of two important notions that are introduced by Climacus: 'the form of a servant' and 'the absolute paradox.' Together they constitute the incognito as a true form. As Climacus makes clear, the god appears in the form of a servant. To the extent that the god really becomes a servant, this appearance is his true form. At the same time, this appearance is also more than that: it is an incognito that confronts the individual with an absolute paradox.

\section{THE FORM OF A SERVANT}

In chapter 2, the hypothetical thought-project is continued in the form of a 'poetical venture [digterisk Forsog]' (PF, 23/SKS 4, 230) which spreads out over the whole book and is taken up again several times. Echoing the invention without an inventor, this poetical venture will result in a poem without a poet. It is for this reason that the authorship of the poetical venture is not clearly assigned, but keeps shifting. In his attempts to grasp the idea of the incognito as a true form, Climacus identifies himself with two types of poets: the mythological and the religious poet. He speaks in the voice of these poets while simultaneously indicating the limits of what they can say. Moreover, at the end of the chapter, Climacus is exposed as a plagiarizer who ends up stealing his words from the god himself. This reveals a third type of poet: the god. This extended play with the attribution of authorship, which evokes a variety of different voices only to immediately question them, is an integral part of what I have called Climacus' poetics of selfincrimination.

Throughout the chapter, Climacus tries to understand the incognito as a true form that is adopted by the god. He cannot address this incognito right away, but can only get a closer understanding of it with the help of an analogy. 'Suppose there was a king who loved an ordinary girl,' he writes. Only to immediately interrupt his own discourse with a possible objection: '-but the reader may already have lost patience with this beginning as it sounds like a mythological adventure [Eventyr] that is by no means systematic' (PF, 26/SKS 4, 233; translation modified). Climacus believes, however, that he should be forgiven for the transgression of telling a mythological adventure. He is, after all, 'only a poet [kun en Digter] who, mindful of Themistocles' beautiful expression, wants to unroll the tapestry of speech [Talens Tappe] lest the work on it be concealed by being rolled up' (Ibid.). This reference to Themistocles indicates that Climacus cannot stick to the systematic vocabulary of the scholarly treatise, but needs to employ the fuller language of mythological poetry to push the boundaries of human language to the limit. Only in this way, can he express the 'kingly concern [kongelige Sorg]' that is 'found only in a kingly soul' 
and which 'many human languages do not name at all' (PF, 28/SKS 4, 235; translation modified).

In Climacus construction of the story about the king, this concern can take on three different forms. First, the king fears that the ordinary girl will not be able to forget the difference in station between her and the king, which might overpower her to such an extent that there is little room left for her to develop her own position. Second, in addition there might be an intellectual difference that separates the ordinary girl from the king, making a mutual understanding between them impossible. ${ }^{10}$ Third, even if the king would raise the station of the ordinary girl by dressing her up and letting her forget the differences between them, the misunderstanding between them would not disappear; it would only remain hidden from her. Although Climacus does not unequivocally state how the king can overcome these concerns, it is clear from the text that it is brought about by a descent. The king could, for instance, adopt the incognito of an ordinary man. This would avoid overpowering the ordinary girl and will ensure that she can determine her own relationship to him with frankness and confidence. For Climacus, the concern of the king provides an imperfect analogy for the concern of the divine teacher. In his view, 'human language as a whole is so self-centered that is has no intimation of such a concern' (PF, 28/SKS 4, 235; translation modified). Hence, it falls within the realm of the ineffable and can only be understood by analogy with the story of the king.

'Thus the task [Opgaven] is assigned,' Climacus states, 'and we invite the poet [Digteren]' (Ibid.). Climacus has already presented himself as a mythological poet earlier. Despite this selfproclaimed role he now feels the need to extend an invitation to a second, religious poet that can address the situation of the god. Climacus does not indicate whether the invitation is accepted by anybody. As a result, the discourse of this religious poet has no clear signature. It is only marked by the invitation preceding it ('we invite the poet') and by a concluding observation ('Thus speaks the poet,' PF, 34/SKS 4, 240). This enables Climacus to approach the realm of the ineffable in a particular way. On the one hand, he advances a position; on the other, he immediately distances himself from it. Let us first look at the position that is taken. The task of the religious poet is 'to find a solution, a point of unity where there is in truth love's understanding, where the god's concern has overcome its pain' (PF, 28/SKS 4, 235). In order to find this point of unity, the god-like the king-has to become the equal of the pupil through a descending movement.

He will appear, therefore, as the equal of the most insignificant person [den Ringeste]. But the most
insignificant person is the one who serves [tjene] others-consequently, the god will appear in the
form of a servant [Tjenerens Skikkelse]. But this form of a servant [Tjenerens Skikkelse] is not
something put on like the king's "cloak of insignificance [Ringheds-Kappe]," which just by flapping
open would betray the king [...]_-but it is his true form [sande Skikkelse]. (PF, 31-2/SKS 4, 238;
translation modified)

In Climacus' view, the god adopts the incognito of a servant, but this incognito is not something that he takes on (as in the case of the king), it becomes his true form. Strictly speaking it is no longer an incognito. The god truly becomes the most insignificant person, the servant. Like the maieutic incognito, the incognito as a true form aims to turn the pupil inward (the first step of education). Unlike the maieutic incognito, however, it also aims to generate a rebirth (the second step). 
Moving forward, Climacus deliberately creates confusion about the implications of all this. Still speaking in the voice of the religious poet, he suggests that the god does everything in his power to ensure that nobody gets offended. ' $\mathrm{He}$ is the god, and yet he walks more circumspectly than if angels were carrying him—not to avoid striking [stodes] his foot, but so that nobody will be trampled into the dust because of being offended at [forarges paa] him.' (PF, 32/SKS 4, 238; translation modified). Moments later, however, he distances himself from this position. 'Thus speaks the poet-for how could it occur to him that the god would reveal himself [aabenbare sig] in this way in order to bring about the most terrifying decision?' (PF, 34/SKS 4, 240; translation modified). It is easy to overlook this self-refutation and to take the discourse of the religious poet as the final word on the self-revelation of the god. However, once it is noticed and taken seriously, it becomes increasingly clear that the religious poet leaves out an important part of the story: the offensive nature of the god's incognito as a true form. As will become clear below, it is only by becoming offensive that the god can make the recipient turn inward in order to provoke a decision that might or might not result in a rebirth.

The religious poet has introduced the notion 'form of a servant,' but to fully understand the implications of this a third poet needs to be brought in: the god himself. To this end, Climacus again interrupts his own discourse to make room for an imaginary opponent who accuses him of plagiarism. Now if someone were to say, "What you are composing [digter] is the crudest plagiarism [lumpneste Plagiat] ever to appear, since it is nothing more or less than what any child knows," well then I will have to hear with shame that I am a liar' (PF, 35/SKS 4, 241; translation modified). Climacus does not deny the charge of plagiarism, but he takes issue with the further specification that it is the crudest plagiarism. 'After all, every poet who steals, steals from another poet, and thus we are all equally crude; indeed, my stealing is perhaps less harmful since it is more easily discovered' (Ibid.; translation modified). If this is the kind of plagiarism the imaginary opponent hints at, there is hardly any reason to single Climacus out as the crudest plagiarist. Maybe, Climacus suggests, the opponent tries to say that the poem was not stolen from another poet? Maybe it has a similar status as a proverb that does not belong to any one poet, but seems to be composed by humanity as a whole? In that case, the accusation would not so much concern the plagiarism itself, but the arrogance with which Climacus spoke by pretending to embody the human race as such. This explanation is dismissed as well. In a sense, each human being is equally close to having composed a proverb as all the others. So again there is no reason to single Climacus out as the crudest plagiarist. A final explanation follows:

You called my conduct the crudest plagiarism, because I did not steal from any single man, did not rob the human race, but robbed the deity or, so to speak, kidnapped him and, although I am only a single human being - indeed, even a crude thief — blasphemously pretended to be the god. (PF, 35-6/SKS 46, 241; translation modified)

The accusation of plagiarism has entered radical new territory here and is supplemented by the accusation of kidnapping, blasphemy and megalomania. At this point, Climacus turns the accusation on its head. It is true that Climacus would not be able to write the poem, it is true that he has stolen his words from someone else. It is exactly for this reason that Climacus has been so ambiguous about his own authorship. He has built up his text in such a way that the reader can only conclude that he is a plagiarist. This conclusion prepares the way for his argument that, ultimately, only the god could have written this poem. After all, it is very well possible that 
human beings imagine themselves to be like the god or that they imagine the god to be like them. However, it is much harder to conceive that 'the god poetized [digtede] himself in the likeness of a human being' (PF, 36/SKS 4, 242). This idea, Climacus suggests, is so absurd that it could not have arisen in a human heart, but must have originated somewhere else. As such, it is an offense to the understanding. This brings us to the second aspect of the incognito as a true form: the absolute paradox.

\section{THE ABSOLUTE PARADOX}

Usually a paradox is understood as an apparent contradiction that despite its counter-intuitive appearance is nonetheless true. Such an apparent contradiction already includes its own resolution. As Climacus suggests, this is not the case with an absolute paradox. The contradiction is real and cannot be resolved, even though it still expresses the truth. Given the absolute nature of the paradox it is hard to say anything about it, without immediately contradicting oneself. As the title of chapter 3-'The absolute paradox (a metaphysical caprice [Grille])'-already announces, Climacus will address this difficulty by juxtaposing two seemingly incommensurable modes: the absolute and the capricious. Later on, the imaginary opponent highlights this point even more: 'You are such a capricious fellow [Grillefanger], I am on to you, there is no way you believe that it would occur to me to be concerned about such a caprice [Grille], something so bizarre or so ludicrous that it doubtless has not yet occurred to anyone and, above all, something so unreasonable that I have to exclude everything in my consciousness in order to even find it' (PF, 46 /SKS 46, 251; translation modified). As Climacus suggests, the absolute paradox expresses something absolutely unknown that will always remain outside of the reach of the understanding. It cannot be fully conceptualized but can only become manifest as something absurd and ludicrous. Hence the reaction of the imaginary opponent is exactly the kind of reaction that Climacus is aiming for.

Speaking in the voice of the religious poet, Climacus already showed that the god adopts the appearance of a servant. Now we have to find out how this is linked to the absolute paradox. Simply put, the absolute paradox can be summarized as follows: the god has become a human being, while also remaining the god; the eternal has become something historical, while also remaining eternal. One side of this absolute paradox— the divine and eternal—remains unknown. The other side - the human manifestation of the god—can be known immediately. That is why the god's appearance as a servant is both an incognito and a true form. It is an incognito insofar as it is an indirect manifestation of the god who, despite this manifestation, ultimately remains the unknown. It is a true form insofar as it is a direct manifestation of the god's willingness to lower himself in order to create a point of unity that bridges the gap between the human and the divine.

The problem is: how can the individual get an intimation of the absolute paradox if one of its sides cannot be known in any way? It needs a kind of indirect communication that presents the unknown in some way or another without representing it as something that can be known after all. To conceptualize this type of indirect communication, Climacus introduces the noun Anstod, which can be translated either as 'collision' or as 'offense.' It introduces the idea of a collision with the unknown. This collision is an offense to the extent that the understanding cannot incorporate the unknown, but runs aground on it. The understanding encounters the unknown as a limit that can only be conceptualized in a negative way, i.e., as something ludicrous and absurd. By colliding with the paradox, human beings get so confused by what appears to 
them as absurd that they no longer understand themselves. In this way, they are turned inward (the first step of education). In response, the understanding either rejects the seemingly absurd by taking offense or accepts it despite its improbable and unreasonable appearance (Climacus calls this faith).

In the appendix to Chapter 3, 'Offense at the paradox (an acoustic illusion),' Climacus analyzes the counterintuitive causality that animates the Biblical conception of 'a stone of stumbling' or 'a rock of offense. ${ }^{11}$ To get a better grasp on this paradoxical causality, he equates the physical interaction between the stone/rock and the foot to the psychological interaction between the offensive one (who is giving offense) and the offended one (who is taking offense). Just as the rock causes the foot to stumble, so the offense that is given becomes the cause for the offense that is taken. At first sight it might seem that the understanding interprets the absolute paradox, judges it ('this is absurd,' 'this is improbable'), and then takes offense. According to Climacus, however, this is an acoustic illusion. 'While, therefore, the offense, however it expresses itself, sounds [lyder] from somewhere else-indeed, from the opposite corner-it is nevertheless the paradox, which echoes [gjenlyder] within it, and this indeed is an acoustic illusion' (PF, 50-1/SKS 4, 255; translation modified). In relation to the paradox, the understanding is like the dummy of a ventriloquist. The offense seems to be invented by the understanding, but in fact it originated with the paradox. Its expressions are based on an acoustic illusion. As Climacus argues, the understanding does not articulate its own position, but simply parrots the paradox, 'just as someone carricaturing another does not invent anything, but only makes a distorted copy of someone else.' (PF, 51/SKS 4, 254; translation modified). Instead of being a true invention, offense is merely a distorted copy of the unknown that is given by the paradox. In this sense, the understanding merely steals its ideas from the paradox. This already makes clear why Climacus relies on a poetic of self-incrimination. In relation to the paradox everybody is a thief.

\section{BETWEEN ATTACK AND DEFENSE}

As we have already seen several times, Climacus adopts the identity of a common thief and dialogizes his discourse by introducing an imaginary opponent who starts accusing him. Throughout the book, this imaginary opponent slowly grows into the role of a real interlocutor who engages with the arguments more fully. The by now familiar charge is repeated. 'But someone may be saying, "Things are truly tiresome with you, for now we have the same story all over again; all the expressions you put into the mouth of the paradox do not belong to you at all"' (PF, 53/SKS 4, 257; translation modified). Again Climacus is caught with stolen goods and accused of thievery, but a new charge is also added. He not only got the words from elsewhere, he also put them into the mouth of the paradox. Climacus admits that some of his expressions are indeed stolen from other authors. At the same time, he insists that these authors were not the true owners of the ideas they expressed, but that these ideas ultimately belong to the paradox. Climacus turns the accusation of the imaginary opponent on its head by suggesting that the second charge- that he has put the words of others into the mouth of the paradox-gives a completely wrong impression of what actually happened. In his view, it is the other way around. Climacus and all the authors he indirectly quotes literally took the words from the mouth of the paradox. Before anyone could articulate these words, the paradox had already expressed them. Anyone else who is saying them is only repeating what the paradox already expressed, regardless of whether these words were meant as an attack ('that is just absurd') or as a defense ('because it is absurd'). 
In the last two chapters of Philosophical Crumbs, the old charge of thievery is reiterated, but in a more subdued voice: 'Once again, knowingly or unknowingly, you have mixed in some words that do not belong to you' (PF, 68/SKS 4, 269; translation modified) and 'you always mix in some little phrase that is not your own' (PF, 105/SKS 4, 301). More importantly, the imaginary opponent's accusatory mode of speaking now repeatedly transforms into its exact opposite. A laudatory mode of speaking that touches upon jealousy: 'I already catch a glimpse of the ramified implications, even if it surprises me that I did not think of it myself and I would give a great deal to be the one who devised it' (PF, 69/SKS 4, 270; translation modified). In a sense, the accusatory and the laudatory mode of speaking are equally problematic since both start from the assumption that it is important to mark who is the owner of the intellectual property that is on display, whereas the whole point is that these ideas cannot belong to anybody since they originate with the god. That is why Climacus has been showing throughout that he was not the one who invented it, but that he only knows it from the paradox.

By employing these two modes of speaking-accusatory and laudatory-at once, Climacus again dialogizes his own discourse. Neither the accusatory mode that fits an attack on Christianity, nor the laudatory mode that matches its defense, is given a decisive impetus. Instead, both these responses are invoked at the same time. In a journal entry, Kierkegaard describes this strategy as follows: 'Joh[annes] Cl[imacus] kept the matter dialectically at a point where no one could see directly whether it was an attack on Xnty or a defense, but that it depended on how things were with the reader, what he got out of the book' (KJN 8, 113/ SKS $24,69)$. In this way, Climacus assures that nothing resolute can be assigned to him as a separate instance of authority that hovers over the text and guards it, but that the reader becomes responsible for the stance that is taken.

\section{CONCLUSION}

The discourse of Philosophical Crumbs is constantly caught up in ambiguities. From the start, Climacus keeps insisting that he is only engaged in a hypothetical thought-project, the aim of which is to discover what it means to go further than Socrates. By presenting the orthodox views of Christianity as a hypothetical thought-project that he just invented, Climacus not only becomes a thief and a plagiarizer, but also remains an outsider who addresses an existential issue in a completely abstract way. At the same time, he highlights this contrast by emphasizing the existential nature of his thought-project and by incriminating himself. I have analyzed this rhetorical strategy as a poetics of self-incrimination. By adopting the identity of a thief, Climacus tries to replicate the incognito as a true form. To the extent that Climacus really turns out to be a thief, this adopted identity is his true form. To the extent that he tries to confront his readers with the paradoxical nature of a non-Socratic conception of truth, it is an incognito. The aim of this incognito is not to hide his own plagiarism, but to draw attention to the fact that going further than Socrates means that the truth needs to be stolen from somewhere else. This is the provocative logic of his thought-project: either we go back to Socrates or we incriminate ourselves and admit that we are thieves. 


\section{RELATED TOPICS}

'Methodology and the Kierkegaardian Mind,' Jamie Turnbull; 'Kierkegaard's Existential Mimesis,' Wojciech Kaftanski

\section{REFERENCES}

Bakhtin, Mikhail (1993) Problems of Dostoevsky's poetics, C. Emerson (trans.), Minneapolis: University of Minnesota Press.

Blanchot, Maurice (1983) 'The Athenaeum,' Studies in Romanticism: Des Allemagnes: Aspects of Romanticism in France, Vol. 22, No. 2, 163-172.

Boven, Martijn (2018) 'A theater of ideas performance and performativity in Kierkegaard's Repetition, in Eric Jozef Ziolkowski (ed.), Kierkegaard, Literature, and the Arts, Evanston, Illinois: Northwestern University Press, 115-130.

Conway, Daniel (2004) 'The drama of Kierkegaard's Philosophical Fragments', in Kierkegaard Studies Yearbook 2004, Berlin: De Gruyter, 139-160.

Demosthenes (1939) Orations, Volume V: Orations 41-49: Private cases, A. T. Murray (trans.), Loeb Classical Library 346, Cambridge, MA: Harvard University Press.

Evans, C. Stephen (1993) Passionate reason: Making sense of Kierkegaard's Philosophical Fragments, Bloomington, IN: Indiana University Press.

Hale, Geoffrey A. (2002) 'The other proposition: Philosophical Fragments and the grammar of life,' in Kierkegaard and the Ends of Language, Minneapolis, MN: University of Minnesota Press.

Harrison, A.R.W. (1971) The law of Athens: Procedure, Oxford: Clarendon Press.

Hannay, Alastair (2009) 'Note on the translation,' in Søren Kierkegaard, Concluding Unscientific Postscript to the Philosophical Crumbs, A. Hannay (trans.), Cambridge, MA: Cambridge University Press, xxxvii- xl.

Howland, Jacob (2006) Kierkegaard and Socrates: A study in philosophy and faith, Cambridge, MA: Cambridge University Press.

Lacoue-Labarthe and and Jean-Luc Nancy (1988) The Literary Absolute : The Theory of Literature in German Romanticism, Albany, N.Y.: State University of New York Press.

Muench, Paul (2006) Kierkegaard's Socratic task. Dissertation, University of Pittsburgh.

Plato (1921). 'Theaetetus,' in Theaetetus/Sophist, H. N. Fowler (trans.), Loeb Classical Library 123, Cambridge, MA: Harvard University Press, 1-258.

Plato (1997) 'Meno,' G.M.A. Grube (trans.), in Complete Works, J. M. Cooper (ed.), Indianapolis, IN: Hackett Publishing Company, 870-897.

Piety, M.G. (2009) 'Introduction,' in Søren Kierkegaard, Repetition and Philosophical Crumbs, M.G. Piety (trans.), Oxford: Oxford University Press, vii-xxix.

Schlegel, Friedrich von (1991) Philosophical Fragments, Peter Firchow (trans.), Minneapolis: University of Minnesota Press.

Shakespeare, William (2003) Twelfth night or what you will (The New Cambridge Shakespeare), E. S. Donno (ed.), Cambridge, MN: Cambridge University Press.

\section{FURTHER READING}

Boven, Martijn (2014) 'Incognito,' in S. Emmanuel, W. McDonald and J. Stewart (eds), Kierkegaard Research: Sources, Reception and Resources, vol. 15 (Kierkegaard's Concepts), tome 3, Farnham: Ashgate, 231-38.

This entry discusses how the notion of 'incognito' is understood by Kierkegaard's pseudonyms. 
Fenves, Peter (1993) 'Autopsies of faith: Philosophical Fragments,' in 'Chatter': Language and History in Kierkegaard, Stanford, CA: Stanford University Press, 113-144.

In line with his overall focus on the notion of 'chatter,' Fenves' fascinating analysis focuses on language in Philosophical Crumbs by highlighting the play of jest and earnestness, the strange practice of naming, and the mock dialogues of the imaginary opponent.

Mulhall, Stephen (1999) 'God's plagiarist: the Philosophical Fragments of Johannes Climacus,' in Philosophical Investigations 22:1, 1-34.

In this article, Mulhall interprets Climacus' writing strategy as an attempt to enact the perceived errors of his intended readers in order to make them aware of these errors and to provide an antidote.

\section{Pons, Jolita (2004) 'Chapter 6: Stealing a gift,' in Stealing a Gift: Kierkegaard's Pseudonyms and the} Bible, New York: Fordham University Press.

This chapter focuses on the use of Biblical quotations in Philosophical Crumbs and their status as stolen words. By interpreting the Bible as a gift, Pons intriguingly suggests that stealing these words simply means not accepting them, robbing oneself of what was given.

\section{NoTES}

${ }^{1}$ In the English-speaking world, the book came to be known as Philosophical Fragments or a Fragment of Philosophy. However, as Hannay remarks, "Crumb" just is a closer translation of "Smule" than is "Fragment" (2009: xxxvii). Piety puts it even more strongly: "fragments" is not among a dictionary's favoured options for "Smuler," and it guarantees that the nimble irony of that topsy-turvy title is lost' (2009: xvi). The word 'smule' is often used in the sense of a small particle of bread. As such, it does not so much suggest incompleteness, but rather refers to

By choosing the title Philosophical Fragments for their translation of Climacus' book, the English translators accidently invoked the romantic genre of the fragment. Upon reading the book, the reader will soon discover that Climacus does not adopt this genre, but relies on another type of writing, which we now have to specify. Climacus uses two different terms to indicate this new genre: smule (crumb) and piece (insignificant written work; note; scribble). In a draft version the title page reads: 'Philosophiske Piecer Smuler [Philosophical Seribbles Crumbs].' (Tekstredegørelse SKS 4, 180). This indicates two things. First, the terms smule and piece refer to the same mode of writing. For that reason, I will take them as references to a single genre. Second, although the preface keeps referring to piecer rather than smuler, the change in the title suggests that Climacus ultimately prefers the latter over the former. That is why I will refer to this mode of writing as the genre of the crumb (den smule). What would this genre look like? To get a better grasp on this, let us first give a brief characterization of Romantic genre of the fragment from which it differs.

There is no single definition of the genre of the fragment available. Each fragment defines the genre and at the same time displaces the definitions given by other fragments. The often-quoted Athenaeum fragment 53 indicates why this displacement is necessary: 'For the mind it is just as fatal to have a system and not to have one: it simply has to take the decision to combine the two.' (Schlegel 1991: 24; translation modified) Hence, the fragment is a discontinuous form that operates in the dialectical tension between creating a system and simultaneously displacing and dismantling it. In his article 'The Athenaeum,' Maurice Blanchot describes this as 'the search for a new form of fulfillment that mobilizes - renders mobile - the whole even while interrupting it in various points.' (Blanchot 1983: 171) In his view, the fragments operate within a field that is constituted by all the other fragments to which it somehow relates, even though this relation cannot be understood in terms of a part-whole distinction. As Blanchot suggests, this field is determined by 'the interval (a wait and a pause) that separates the fragments and that makes this separation the rhythmic principle of the work and its structure.' (Ibid.: 172) Together, the fragments do not generate a unity, but open up 'new relations that exempt themselves from unity, just as they exceed the whole.' (Ibid.; translation modified) As such, the fragments generate an instable and discontinuous system that simultaneously organizes and disorganizes itself, made possible by its own intervals. 
In contrast to the Romantic genre of the fragment, the new genre of the crumb that Climacus intrdocues does not aim to revolutionize the system from within by breaking it up in a dynamic system of seperated fragments. Instead, Climacus undermines his own position by denouncing any claim of authority and highlighting the insignificance of what is said. The aim of this self-deprecating rhetoric is not to make the character of the author appear more attractive through false modesty. On the contrary, Climacus actively tries to push readers away in order to force them to make a decision that discloses their own views. He relies here on the paradoxical causality that animates the Biblical conception of 'a stone of stumbling' or 'a rock of offense'. Climacus not only discusses this paradoxical causality, but also tries to repeat its movement by highlighting the offensive nature of Christianity.

${ }^{2}$ This play is continued in the rather elaborate Postscript to the Philosophical Crumbs that is also attributed to the pseudonym Climacus.

3 After a long, unauthorized absence the jester Feste is (playfully) confronted by Maria, a gentlewoman in Lady Olivia's household: 'My lady will hang thee for thy absence.' In response, Feste jests about the invoked punishment and states, among other things: 'Many a good hanging prevents a bad marriage' (2003: 70). Kierkegaard used the German translation by Schlegel and Tieck and translated it into Danish as 'Bedre godt hængt end slet gift' (SKS 4, 214).

4 The notion 'going further' echoes Hegel's speculative vocabulary. It is used in an ironic way and marks a break with the Socratic viewpoint, without presenting this break as a progression in the speculative sense.

${ }^{5}$ I have at various points modified the Hong \& Hong translation. This does not signify that I take issue with their translation; it simply is a way to get a better sense of the language Kierkegaard used.

${ }^{6}$ Socrates states at the beginning of the Meno: 'I myself, Meno, am as poor as my fellow citizens in this matter, and I blame myself for my complete ignorance about virtue' (Plato 1997: 871/71b). A bit further on he adds: 'I have never yet met anyone else who did know [what virtue is]' (Ibid., 872/71c).

${ }^{7}$ Early on, Meno defines virtue as the ability 'to rule over [archein] people' (Plato 1997: 873/73d). In response, Socrates immediately starts to complicate the issue: 'is virtue the same in the case of a child or a slave, namely, for them to be able to rule over [archein] a master [despotou], and do you think that he who rules [archon] is still a slave?' (Ibid.). Throughout the dialogue, there are several ironic references to Meno as the one who directs and rules Socrates: 'Because you are forever giving orders in a discussion, as spoiled people do, who behave like tyrants as long as they are young. And perhaps you have recognized that I am at a disadvantage with handsome people, so I will do you the favor of an answer' (Plato 1997: 876/76b-c). And: 'If I were ruling over [arkho] you, Meno, and not only over myself, we would not have investigated whether virtue is teachable or not before we had investigated what virtue itself is. Over yourself you do not even attempt to rule [archein] (in order to remain free), but over me you attempt to rule [archein] and you actually rule [archeis], for that reason I will concede to you-for what can I do?' (Plato 1997: 887/86d, translation modified).

${ }^{8}$ Socrates' phrasing is obviously ironic. The aim is not to present the actual inquiry, but to identify the slave with Meno. The latter said earlier in the dialogue: 'I have made many speeches about virtue before large audiences on a thousand occasions, very good speeches as I thought, but now I cannot even say what it is. I think you are wise not to sail away from Athens to go and stay elsewhere, for if you were to behave like this as a stranger in another city, you would be driven away for practicing sorcery' (Plato 1997: 879/80b). Note that Meno admits his perplexity, but blames it on Socrates' sorcery rather than on his own lack of knowledge.

9 In Problems of Dostoevsky's Poetics, Mikhail Bakhtin introduces the notion óvókpırıৎ (anacrisis), an ancient Greek juridical term, to describe a rhetorical technique that is employed here. 'Anacrisis was understood as a means for eliciting and provoking the words of one's interlocutor, forcing him to express his opinion and express it thoroughly.' Unfortunately, Bakthin does not offer any evidence to support this interpretation of anacrisis. It comes from ana, 'up' and krino, 'closely examining' and refers, to a legal procedure that involves questioning of some kind. As Harrison indicates, however, it is 'much more difficult to define precisely what the aim of this questioning might be' (1971: 95). A possible source for Bakhtin might have been an archaic law that is described by Demosthenes in Against Stephanus II: 'The two parties to a suit shall be compelled to answer one another's questions' (1939: 251). According to Lämmli this law indicates that 'the anacrisis gave litigants some chance of seeing into their opponents' cards; for they could put questions to them which the opponents had to answer, though they were not forced to furnish evidence on the points raised.' (Summarized in Harrison 1971: 98, footnote 2). Despite the rather scanty evidence that anacrisis was indeed what Bakthin takes it to be, his idiosyncratic understanding of the term provides a good basis for understanding the underlying rhetorical structure of the maieutic incognito.

10 There is a thinly disguised reference here to Kierkegaard's engagement with Regine Olsen. In his Journals and Notebooks Kierkegaard often explicitly refers to his own incognito (e.g. KJN 4: 256; 5: 259-60, 287; 6: 75, 237; 7: 129, 213, 236; 8: 297). In relation to Regine, these references remain more hidden. 
11 The locus classicus for the Biblical conception of offense can be found in Isaiah 8: 14. Two notions are introduced here: eben negeph (a stone the makes the foot trip) and tsuwr mikshowl (a rock that becomes a cause to fall). In the Greek New Testament, the words from Isaiah are quoted in Greek translation, for instance in 1 Peter 2:8. The stone becomes a lithos proskommatos (a stone of stumbling), derived from proskopto: to strike against. The rock becomes a petra skandalou (a rock of offense). 